\title{
KEHIDUPAN MULTIKULTURALISME SWITHA SEBAGAI ANAK SUKU TAMIL DI KOTA MEDAN DALAM PENYUTRADARAAN FILM DOKUMENTER POTRER “NIRAM"
}

\author{
Yunalistya Sakanti Putri \\ Agnes Widyasmoro \\ Lilik Kustanto \\ Jurusan Film \& Televisi, Fakultas Seni Media Rekam, Institut Seni Indonesia Yogyakarta \\ Jl. Parangtritis km. 6.5 Yogyakarta Telp. (0274) 381047
}

\begin{abstract}
ABSTRAK
Suku Tamil sendiri berasal dari Asia Selatan atau biasa disebut dengan India. Suku Tamil memiliki persebaran yang cukup besar dan berpusat di Sumatera Utara sejak zaman penjajahan belanda pada abad 7 masehi. Multikulturalisme adalah sebutan untuk seseorang memiliki pandangan tentang ragam kehidupan di dunia, ataupun kebijakan kebudayaan yang menekankan tentang penerimaan terhadap adanya keragaman.

Film dokumenter "Niram" merupakan film dokumenter bergenre potret yang akan memberikan informasi langsung secara visual bagaimana multikulturalisme menjadi bagian dari kehidupan sosial seorang anak Suku Tamil sebagai salah satu golongan suku minoritas yang berada di lingkungan multikultur di Kota Medan dengan metode pemaparan cinéma vérité sebagaimana perwujudan dalam karya ini juga dibangun saat pengambilan gambar ataupun dalam proses riset guna memberikan fakta yang terjadi di lapangan dan melalui statement Switha sebagai subjek utama serta narasumber pendukung lainnya.

Penerapan genre potret dan metode pemaparan cinéma vérité dalam film dokumenter "Niram" ini menghasilkan karya yang menunjukkan bagaimana perspekstif anak Suku Tamil yang bernama Switha dalam kehidupan multikulturalisme secara sosial di Kota Medan. Pada dokumenter ini juga bertujuan untuk memberikan informasi kepada penonton bahwasannya saling menghormati tanpa melihat perbedaan adalah hal yang baik untuk dilakukan tiap individu tanpa melihat budaya, suku, agama, ras, dan strata sosial.
\end{abstract}

Kata Kunci: Multikulturalisme, Suku Tamil, Dokumenter Potret, Cinéma Vérité.

\section{PENDAHULUAN}

Penduduk Indonesia memiliki lebih dari ratusan suku, agama, ras dan kebudayaan, salah satunya adalah Suku Tamil. Suku tamil berasal dari Bangsa Dravida di India, Asia Selatan. Salah satu kota yang menjadi salah satu tempat persebaran banyaknya suku tamil yakni Medan, Sumatera Utara. Suku yang tersebar di Sumatera Utara juga dibilang beraneka ragam seperti Melayu, Batak, Tionghoa,
Jawa dan banyak lagi tapi salah satunya adalah suku tamil. Persebaran suku tamil di Indonesia dikarenakan memiliki angka yang cukup signifikan di Sumatera Utara yakni sekitar 40,000 jiwa. Walaupun begitu persebaran suku tamil sendiri masih sangat kecil dibanding dengan persebaran suku lainnya yang ada di Kota Medan, karena itu suku tamil juga termasuk golongan suku minoritas di Sumatera Utara. Multikulturalisme secara tidak langsung 
telah menjadi bagian dari hidup penduduk Indonesia dikarenakan banyaknya suku budaya yang ada. Multikulturalisme dapat juga dipahami sebagai pandangan dunia yang kemudian diwujudkan dalam kesadaran politik (Azyumardi Azra, 2007). Multikulturalisme mempunyai ikatan yang erat dengan Bhinneka Tunggal Ika dimana adanya perwujudan suatu kebudayaan yang akan menjadi pemersatu bangsa. Di Sumatera Utara tepatnya di Kota Medan, multikulturalisme berperan penting dalam kelangsungan kehidupan sosial antar suku baik di kota Medan. Sumatera Utara terkenal dengan multikulturnya, lalu dengan suara keras, menggunakan bahasa melayu serta hokkien di berbagai kata serapan salah satu bentuk multikulturalisme yang sudah menjadi bagian dari keseharian masyarakat Medan.

Karya film dokumenter "Niram" adalah perwujudan bagaimana anak suku Tamil berinteraksi langsung ke banyak temannya di lingkungan sekolah secara sosial dan memberikan perspektif baru kepada orang mengenai orang yang memiliki suku minoritas. Film dokumenter ini menggunakan genre potret agar dapat lebih terarah serta fokus pada objek yakni multikulturalisme dalam kehidupan Switha serta pendekatan dengan cinéma vérité digunakan untuk membantu penggambaran realitas dalam kehidupan Switha pada film dokumenter ini.
Niram sendiri berasal dari Bahasa Suku Tamil yang berarti Warna. Ide untuk mengangkat karya Niram menjadi sebuah objek penciptaan berawal dari banyaknya isu perselisihan yang menyangkut tentang suku budaya hingga agama antara satu dengan lainnya. Semboyan Bhinneka Tunggal Ika kini perlahan tidak diperhatikan dan masingmasing kelompok mulai berusaha menjadi yang terbaik dengan cara menjatuhkan suku, budaya, agama dan ras lainnya yang mengakibatkan perpecahan secara tidak langsung. Perwujudan karya objek Niram ini nantinya akan dikemas dalam bentuk dokumenter potret yang isinya kehidupan sosial serta keseharian seorang anak bersuku Tamil di lingkungan sekolah. Dengan cara berikut dapat memberikan informasi hubungan baik antar suku serta keberagaman serta terpeliharanya kedamaian diantara perbedaan antar budaya salah satu yakni suku yang ada di Medan yakni suku Tamil dengan suku lainnya seperti Melayu, Batak, Aceh dan sebagainya.

Tujuan untuk membuat karya dokumenter ini dilatarbelakangi oleh berbagai hal yang ingin disampaikan kepada khalayak luas dan diharapkan dapat memberikan manfaat, salah satunya yakni memberikan informasi bagaimana Suku Tamil dan budayanya, dan memberikan perspektif baru mengenai suku yang tergolong minoritas. 
Tinjauan karya yang digunakan dalam rancangan penciptaan karya dokumenter ini meliputi tiga film dokumenter. Karya dokumenter pertama yang menjadi tinjauan karya untuk film dokumenter Niram ini adalah Goodnight \& Goodbye. Goodnight \& Goodbye merupakan sebuah film dokumenter dari Taiwan karya Adon Wu yang dibuat pada tahun 2018. Film ini adalah sekuel setelah film pertama Adon Wu dengan judul Swimming on the Highway pada tahun 1998. Di karya sebelumnya Adon Wu sebagai sutradara dan subjeknya yakni Tom memiliki konflik dan percakapan yang akhirnya tidak selesai karena menyangkut psikologis. Lalu 20 tahun kemudian sang sutradara kembali dalam perjalanan menuju Puzi, Provinsi Chiayi untuk bertemu Tom dan berkeinginan untuk meluruskan kejadian 2 dekade silam. Selanjutnya ada karya dokumenter dari Paweł Łoziński yang berjudul Father and Son. Film ini bercerita tentang Pawel sebagai anak dan Marcel sebagai ayah yang sedang dalam perjalanan mengelilingi Eropa menggunakan mobil dan singgah ke prancis untuk pergi mengunjungi tempat peristirahatan terakhir ibu Pawel. Sepanjang perjalanan itu mereka bercerita tentang masa lampau dan berbagi sebagaimana percakapan antara seorang ayah dan anak dengan kedekatan yang lebih dari sekedar hubungan orang tua dan anak. Dan tinjauan karya terakhir adalah karya dari Anita Reza Zein yang berjudul Dulhaji
Dolena. Dulhaji adalah seorang laki - laki berusia 40 tahun, merupakan salah satu warga korban banjir rob di desa Api - Api (Pekalongan, Jawa Tengah). Dulhaji bersama dengan anak dan istrinya memilih untuk tetap tinggal di rumahnya, meskipun banjir rob telah menimpanya dan warga lain sejak tahun 2009. Hal tersebut di karenakan Dulhaji tidak memiliki cukup biaya untuk pindah dan meninggalkan rumahnya ke tempat lain. Ketiga karya yang menjadi tinjauan karya film dokumenter Niram ini memiliki kesamaan dalam metode pemaparan cinéma vérité dan genre potret.

\section{OBJEK PENCIPTAAN}

\section{Kota Medan}

Kota ini merupakan kota terbesar ketiga di Indonesia setelah Jakarta dan Surabaya, serta kota terbesar di luar Pulau Jawa. Medan berawal dari sebuah kampung yang didirikan oleh Guru Patimpus di pertemuan Sungai Deli dan Sungai Babura. Hari jadi Kota Medan ditetapkan pada tanggal 1 Juli 1590. Selanjutnya pada tahun 1632, Medan dijadikan pusat pemerintahan Kesultanan Deli, sebuah kerajaan Melayu. Sumatera ini, dapat penulis kelompokkan kepada tiga kategori. Yang pertama adalah penduduk setempat yang terdiri dari: Karo, Pakpak-Dairi, Simalungun, Batak Toba, Mandailing-Angkola, Pesisir, Nias, dan Melayu. Kadangkala disertakan pula etnik Lubu dan Siladang. Yang kedua adalah etnik 
pendatang dari nusantara yang terdiri dari: Aceh Rayeuk, Tamiang, Alas, Gayo, Minangkabau, Banjar, Sunda, Jawa, Bugis, Makasar, dan lainnya. Yang ketiga adalah etnik-etnik pendatang Dunia seperti: Tamil, Punjab, Hindustan, Arab, Hokkian, Khek, Hakka, Kwantung, berbagai etnik dari Eropa, dan lainnya.

\section{Suku Tamil}

Suku Tamil menurut sejarah mereka adalah pendatang yang ada awalnya sebagai kuli di perkebunan Deli. Mereka pertama kali dibawa masuk ke Indonesia oleh pemerintah Belanda pada abab ke 19, mereka umumnya dibawa sebagai pekerja pada sejumlah perkebunan di kota Medan, pulau Sumatera. Sebagian besar berasal dari India bagian selatan, namun tidak sedikit pula yang berasal dari India bagian utara. Masyarakat India terbagi menjadi 5 sub kelompok dalam persebarannya di Indonesia yakni Punjabi, Tamil, Sindhi, Telegu, dan Gujarat.

Kebanyakan dari masyarakat Tamil beragama Hindu, namun tidak sedikit pula yang beragama Islam dan Kristen. Istilah "keling" di Sumatera Utara digunakan untk menyebut orang India yang identik dengan kulit gelap, khususnya masyarakat Tamil dan julukan ini cenderung memiliki konotasi negatif. Padahal sebenarnya istilah kata "keling" ini digunakan untuk orang Jawa yang berasal dari kerajaan Kalingga di Jawa Tengah. Namun orang Belanda membuat kesalahan pengucapan kata Kalingga sehingga menjadi kata keling. Hal ini juga berdampak pada penyebutan nama daerah yang sampai saat ini merupakan salah satu pusat kebudayaan dan pengembangan etnis Tamil yaitu Kampung Keling atau sekarang disebut dengan Kampung Madras.

\section{Switha}

Switha adalah salah satu anak suku tamil yang lahir pada tanggal 2 Juli 2002 dan besar di Medan. Switha kini tinggal di Jalan T.B Simatupang Gang Wakaf nomor 3, Kelurahan Lalang, kecamatan Medan Sunggal, Kota Medan 20351. Kedua orang tuanya juga lahir di Medan dan bukan dari migrasi langsung dari India. Switha yang kini sudah mengenyam pendidikan sekolah menengah atas di salah satu sekolah swasta di Medan serta menjadi salah satu suku/etnis yang minoritas di lingkungan sekolahnya.

Pengalaman Switha sebagai anak suku tamil sendiri tidak terlepas dari adanya olokan dari beberapa temannya dan orang lain terutama dikarenakan ras atau warna kulitnya yang berbeda dan sebagai pemeluk agama hindu india. Awalnya Switha merasa minder dan tidak percaya diri dan itu mengakibatkan dia tidak banyak berinteraksi serta memilih untuk diam jika ada dilingkungan luas yang bukan berasal dari suku yang sama. 


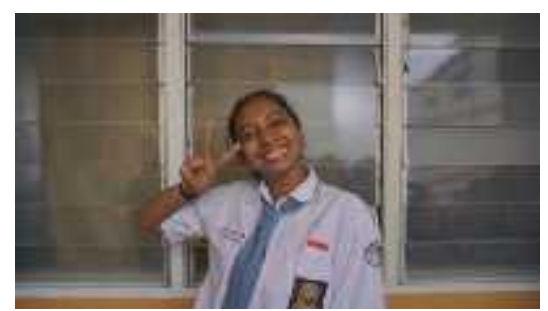

Gambar 1. Switha saat di sekolah

( Dokumentasi pribadi)

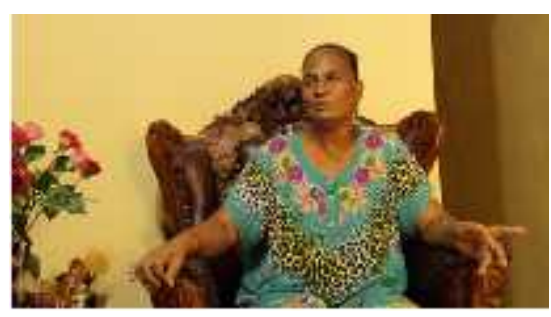

Gambar 2. Nenek Switha saat di rumah

( Dokumentasi pribadi)

Hal ini terjadi tidak berlangsung lama, setelah beradaptasi dengan lingkungan sekolah yang menerima dia sebagai seorang Tamil dan juga dirinya menjadi salah satu dari siswa berprestasi dan berhasil mengharumkan nama sekolahnya, Switha tidak merasa terkucilkan lagi. Karena interaksi ini yang terjadi setiap hari dan berulang-ulang, multikulturalisme sudah berperan dalam kehidupan sosial pada seorang Switha. Begitupun multikulturalisme ini sendiri juga sudah menjadi bagian dari teman-temannya yang dimana dapat dilihat bahwa mereka menerima, menghormati satu sama lain dan menanamkan nilai kesetaraan derajat, tidak ada pengelompokan antara minoritas dan mayoritas antar suku di lingkungan sekolah.

\section{Nenek Switha}

Scathira Gandi atau biasa disebut dengan sapaan Amay dalam Bahasa tamil yang artinya Nenek adalah sosok yang sangat berpengaruh dalam kehidupan Switha sejak kecil hingga sekarang. Lahir pada 14 Januari 1956 dan telah menjadi wali sejak orang tua Switha memutuskan untuk berpisah dan tidak mengurus Switha dan abangnya. Neneknya kini bekerja sebagai pedagang kain dari pintu ke pintu serta menawarkan kain dagangannya ke tetangga dan lingkungan rumahnya untuk ikut membantu abang Switha untuk memenuhi kebutuhan sehari-hari keluarga kecilnya. Perannya menjadi seorang nenek sekaligus sosok ibu untuk anak-anaknya tidak membuatnya berat hati menjalani hidup seperti sekarang ini.

\section{Shuges}

$\underline{\text { Salah satu anak suku tamil yang }}$ sekarang berada di kelas XII dan merupakan teman satu sekolah Switha. Shuges sendiri adalah murid pindahan dari Bandung dan kini menetap di Kota Medan. Shuges sebenarnya adalah orang yang lebih memilih untuk diam dan tidak banyak bertindak. Dalam beberapa kesempatan Shuges juga lebih terlihat diam dan tidak ingin memberi tanggapan karena takut, tetapi akhirnya setelah merasa nyaman untuk berbicara dia bisa berbincang dengan $\underline{\text { Switha serta teman-temannya yang lain dan }}$ memperkuat statement Switha tentang isu intoleran yang sempat terjadi pada dirinya.

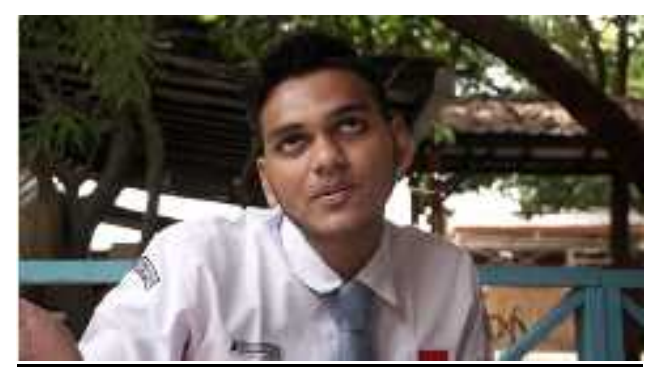

Gambar 3. Shuges saat di sekolah (Dokumentasi pribadi) 


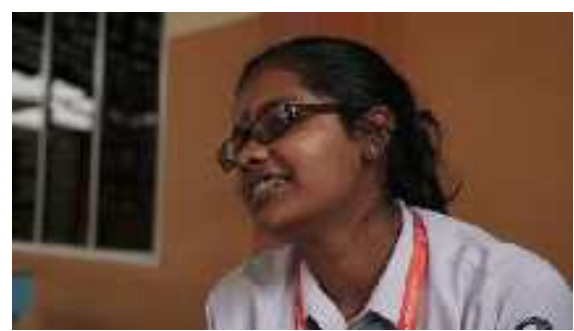

Gambar 4. Shindya saat di sekolah ( Dokumentasi pribadi)

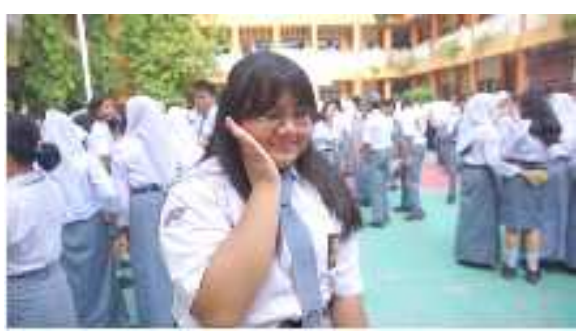

Gambar 5. Cerine saat di sekolah ( Dokumentasi pribadi)

\section{Shindya Kalita}

Teman seangkatan Switha namun berbeda kelas serta jurusan, termasuk anak yang aktif. Shindya adalah anak dari keturunan Tamil yang taat akan agama dan sering menghabiskan waktunya didalam pura sekolah. Shindya ikut menjadi salah satu pendukung statement Switha berkaitan dengan isu intoleran yang terjadi pada dirinya serta temannya dahulu.

\section{Cerine Khosasi}

Sahabat yang sudah bersama Switha sejak masuk sekolah menengah atas. Sekelas hingga menjadi teman satu ekstrakulikuler radio yang juga Switha tekuni. Cerine adalah salah satu siswa beretnis Tionghoa di sekolah. Cerine orang yang ceria dan suka bersenda gurau kepada siapa saja. Perbedaan agama serta ras yang dimilikinya tidak menjadi alasan untuk tidak berteman bahkan bersahabat dengan Switha hingga saat ini. Cerine sendiri memiliki cita-cita yang sama dengan Switha untuk kedepannya yakni melanjutkan studi ke kota Yogyakarta.

\section{KONSEP KARYA}

Film dokumenter "Niram" mengambarkan kehidupan sosial anak suku tamil yang akan diwakilkan oleh Switha. Film dokumenter ini memberi motivasi dan informasi bahwa multikulturalisme adalah hal yang penting dalam kehidupan bersosialisasi antar suku budaya baik itu untuk suku minoritas maupun mayoritas di suatu daerah tertentu. Film dokumenter "Niram" ini di paparkan dalam genre potret dan menggunakan pemaparan cinéma vérité. Suku Tamil sendiri menjadi salah satu objek yang menarik untuk diangkat karena memiliki perbedaan kultur yang signifikan. Perbedaan signifikan antar kultur yang dimaksud adalah bagaimana adat istiadat yang dibawa langsung dari India diterapkan di Indonesia yang juga sebenarnya memiliki ragam budaya yang berbeda tiap suku.

Awal proses pembuatan film dokumenter potret "Niram" sutradara akan membangun kedekatan dengan subjek, Switha. Pembangunan kedekataan ini agar subjek dapat merasa tenang dan nyaman untuk membuka diri ketika bercerita dan berbagi pengalamannya dengan sutradara. Pendekatan dan riset terhadap Switha sendiri dilakukan secara bertahap. Sutradara harus memahami terlebih dahulu lingkungan dan karakteristik narasumber. Sutradara melakukan pendekatan dengan berbaur 
dengan keluarga Switha serta temantemannya dengan diawali dengan perbincangan ringan. Setelah mereka merasa nyaman dengan kehadiran sutradara, maka dilakukanlah riset mendalam dengan menggunakan indeep interview. Riset akan diperkuat oleh statement beberapa teman Switha yang mendukung keterkaitan multikulturalisme pada suku tamil itu sendiri. Dengan begitu setelah proses riset dan pengambilan gambar, bahan yang sudah ada akan diolah mengingat cinéma vérité juga akan terbentuk saat proses penyuntingan gambar.

Saat proses pengambilan gambar akan digunakan beberapa teknik gerak kamera. Kesinambungan (shot, scene, sequence, screen direction) tentu dibutuhkan guna menjaga emosi penonton agar selalu terfokus saat menonton karya ini. Proses pengambilan gambar pada dokumenter ini menggunakan perpaduan komposisi gambar berupa ukuran shot size: medium close up, close up, medium shot, full shot, dengan menyesuaikan kondisi pada waktu pengambilan gambar. Dalam konsep sinematografi ini juga terdapat aspek yang ikut membantu terbentuknya genre potret dan gaya cinema verité yakni dengan komposisi yang dibangun dalam frame baik dalam bentuk angle, shot size, bahkan teknik yang digunakan saat pengambilan gambar berlangsung.
Hampir keseluruhan dalam film dokumenter "Niram" ini menggunakan available light atau biasa disebut dengan cahaya alami yang berasal dari matahari. serta cahaya lampu yang berada disekitar lokasi bertujuan untuk mempertahankan gambar yang natural dengan tidak melakukan rekayasa di dalam pengambilan gambar atau momen-momen tertentu. Penggunaan available light dalam banyak momen yang ditangkap karena pada pengambilan gambar yang dilakukan siang hari dan pada dasarnya pembuatan film dokumenter adalah merepresentasikan realita berupa perekaman gambar yang apa adanya.

Konsep suara dalam film dokumenter potret "Niram" yaitu natural sound atau suara alami. Suara ambient atau dialog akan direkam apa adanya menggunakan Rode Video Mic Pro. Di tahapan pasca produksi, penataan suara akan dilakukan yaitu Sound Mixing. Sound Mixing sendiri merupakan proses editing audio menggunakan software Adobe Audition CC 2018 untuk mengoreksi level suara yang terekam. Musik ilustrasi yang digunakan dalam film dokumenter ini merupakan musik daerah yang berasal dari India yang lebih didominasi oleh suara sitar, gendang dan suling.

Karya ini akan menggunakan teknik editing yang mampu menghasilkan gambar yang berkesinambungan. Hal itu karena dokumenter ini bercerita secara beruntut. Dalam konsep penyuntingan gambar, genre 
potret dan pemaparan cinema verité juga dibangun dengan adanya interaksi yang dibangun antar subjek dan sutradara. Shotshot yang menunjukkan pemaparan berdasarkan tujuan awal pembuat film akan di masukan didalam film. Saat sesi wawancara berlangsung akan digunakan metode editing continuity cutting yang bertujuan agar terjadi kesinambungan dengan gambar yang dihasilkan ketika narasumber berbicara. Untuk keseluruhan film ini mengunakan teknik editing pada umumnya, menyesuaikan momen yang ditangkap. Kemungkinan besar penggunaan teknik cut to cut dan jump cut adalah yang paling sering digunakan.

\section{PEMBAHASAN}

Film dokumenter ini berjudul Niram, diambil dari Bahasa Tamil yang artinya warna. Film ini menggambarkan bagaimana kehidupan sosial sehari-hari dalam lingkungan sekolah dari sudut pandang anak suku Tamil bernama Switha yang sebenarnya termasuk golongan suku minoritas di kota Medan.

Film dokumenter genre potret Niram dengan gaya cinéma vérité mengangkat bagaimana multikulturalisme menjadi bagian penting dalam berinteraksi ke sesama manusia yang memiliki perbedaan pada suku budaya masing-masing. Isu intoleran yang terjadi di Indonesia hingga saat ini masih tidak terlepas dari sebagian orang yang memiliki suku, agama, ras serta strata ekonomi yang berbeda dari banyak orang pada umumnya.

\section{Unsur Naratif}

Film dokumenter Niram dibuka dengan beberapa foto-foto lama dari keluarga Switha dari 2 generasi sebelumnya. Foto-foto ini menunjukan awalan tujuan pengenalan dengan cara visual singkat bahwa film dokuementer Niram ini ingin mengangkat kisah yang berkaitan dengan suku Tamil. Setelah foto-foto fade to black, judul akan muncul dalam film. Judul yang dipilih untuk film dokumenter Niram mengingat arti kata niram dalam Bahasa tamil juga berarti warna.

Setelah itu, shot langsung berpindah menuju halaman depan sekolah. Terlihat suasana sekolah yang ramai dengan warna bangunan cerah dan lalu lalang para murid dan wali dalam shot ini. Setelah itu keterangan kembali diberikan bahwa banyaknya anak SMA sedang berkumpul di halaman sekolah karena sedang ada kegiatan dalam menyambut hari kemerdekaan Indonesia. Beberapa shot diperlihatkan bahwasannya banyak etnis yang sedang berada didalam satu halaman tersebut, kemudian mulai menunjukkan fokus kepada salah satu anak Tamil yang sedang berbicara dengan sahabatnya yakni Switha. Switha terlihat tenang sambil berbicara mengenai kelas berapa yang sedang bertanding. 


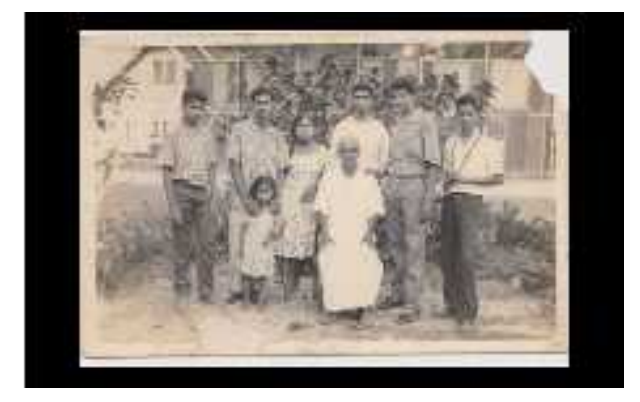

Gambar 6. Still film foto-foto keluarga Switha

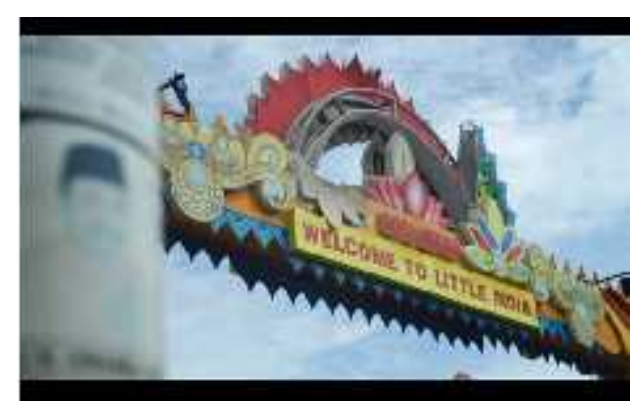

Gambar 7. Still film suasana Little India

Lalu jump cut diterapkan dan shot berpindah ke rumah ibadah hindu yang ada di sekolah yakni pura. Terlihat suasana altar sembahyang untuk umat hindu dan gambar besar Dewa Ganesha sebagai Dewa yang berpengaruh pada pendidikan dan kecerdasan serta beberapa peralatan untuk sembahyang.

Dari awal pembukaan film dokumenter ini shot-shot yang ditampilkan tanpa ada interaksi antara sutradara dan Switha sebagai subjek guna untuk memberikan informasi awal fokus kepada Switha sebagai subjek utama dalam film dokumenter potret Niram. Dalam scene rumah, Switha mulai berbicara mengenai keluarganya dan nenek Switha juga ikut didalamnya. Nenek Switha ikut memberikan informasi bahwasannya multikulturalisme sendiri hadir setelah dia menikah.

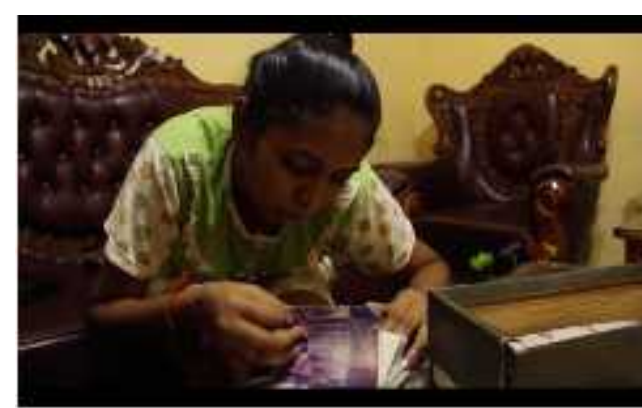

Gambar 8. Still film Switha sedang di rumah

Pada bagian isi dalam film dokumenter potret Niram ini menceritakan bagaimana proses interaksi sosial yang dilakukan Switha terhadap beberapa temannya. Dalam bagian isi ini tema yang diangkat yakni bagaimana perbandingan interaksi dengan teman-temannya memiliki suku yang berbeda. Yang pertama yakni ketika Switha bercerita bersama sahabatnya yakni Cerine. Dalam bagian ini memperlihatkan multikulturalisme berpengaruh dalam kehidupan sosial Switha dan juga Cerine. Cerine adalah anak beretnis Tionghoa. Etnis tionghoa di sekolah Switha sendiri adalah salah satu suku atau etnis yang termasuk golongan mayoritas. Pada scene ini juga diperkuat bagaimana interaksi informal mereka ketika sedang berbicara didepan ruang $\mathrm{BK}$.

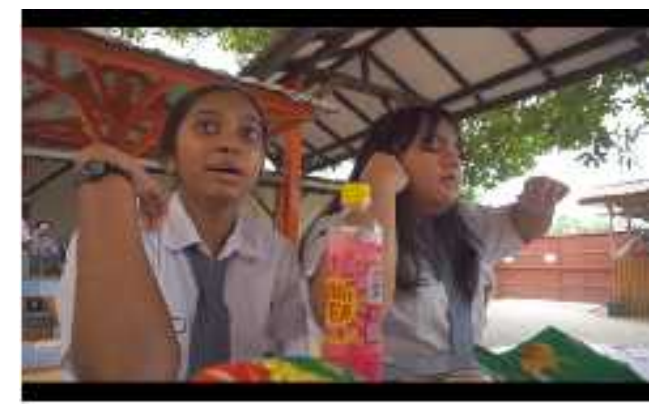

Gambar 9. Still film Switha bersama Cerine sedang berbincang 


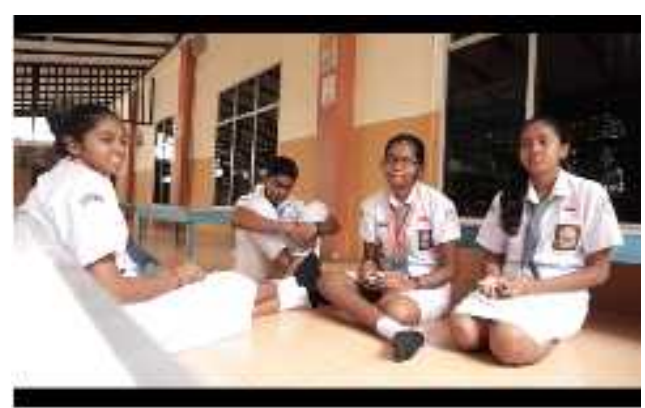

Gambar 10. Still film Switha berbincang dengan teman sesuku Tamil di sekolah

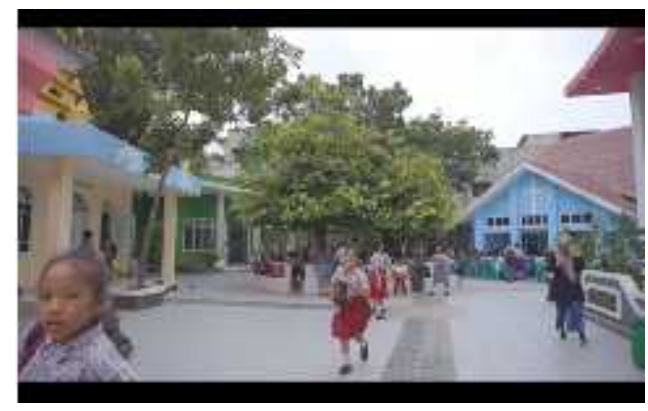

Gambar 11. Still film halaman belakang sekolah

Kebanyakan dari mereka sampai sekarang masing mementingkan ras dan terkadang mendiskriminasi orang-orang yang tidak satu rumpun dan satu ras dengan mereka. Dan perwujudan Cerine juga menjadi salah satu contoh penerapan multikulturalisme itu penting, berteman dengan siapa saja berasal dari suku, agama, ras, strata sosial ekonomi yang berbeda bukan menjadi salah satu halangan untuk bisa berteman baik dengan Switha, seorang yang dari golongan minoritas.

Setelah interaksi dengan Cerine, di bagian isi ini juga di hadirkan bagaimana interkasi Switha dengan teman-teman sesuku Tamilnya yang ada di sekolah. Peristiwa yang berhasil didapatkan saat lesehan ini terjadi ketika mereka sedang berkumpul dan membicarakan hal seputar kepentingan kuil dan pantangan-pantangannya. Dalam kesempatan cinéma vérite diterapkan sutradara melontarkan pertanyaan kepada Switha beserta teman-temannya untuk menyampaikan pendapat mereka terhadap hal yang menyangkut intoleransi. Ada beberapa pernyataan yang dikemukakan oleh Switha dan teman-temannya. Pernyataan teman-teman Switha juga menjadi salah satu hal yang memperkuat statement dimana perlunya menghargai setiap perbedaan yang ada.

Dengan beberapa pernyataan yang disampaikan oleh Switha beserta temantemannya diharapkan penonton dapat berpikir lebih baik dan memikirkan konsekuensi jika melakukan hal tersebut, perilaku yang tidak terpuji tersebut sebenarnya bisa menjadi salah satu hal memicu perpecahan antar budaya yang ada di Indonesia.

Bagian akhir dalam film dokumenter potret Niram ini memberikan informasi dengan Establish halaman belakang sekolah saat hari jumat adalah peristiwa dimana setiap siswa akan pergi beribadah dirumah ibadah masing-masing. Muslim melaksanakan ibadah shalat juma'at di masjid, Nasrani melaksanakan ibadah jumat di gereja, begitu juga untuk pemeluk agama Buddha dan Hindu yang melakukan sembahyang di vihara dan pura.

Shot selanjutnya memperlihatkan bagaimana suasana upacara 17 Agustus yang dilaksanakan disekolah. Beberapa shot yang 
diabadikan dalam upacara bendera kali ini dapat terlihat keanekaragaman yang terwakilkan oleh siswa serta guru yakni seperti petugas paskibra dan saat guru berbaris di lapangan sekolah. Hal berikut memperlihatkan sisi positif dan keberagaman yang ada di Indonesia. Rasa cinta kepada negara yang ditanamkan kepada diri terlihat dengan keindahan macam ragam pakaian adat yang di pakai oleh para guru dan petugas paskibra dengan adanya perbedaan diantara suku mereka tetapi menjadi petugas pengibar bendera.

Lalu dilanjutkan perpindahan shot dimana Switha beserta teman-temannya yang bersuku Tamil sedang melakukan kegiatan di dalam pura. Keseharian mereka saat jam pelajaran kosong, saling berbincang satu dengan yang lain hingga membenarkan altar untuk sembahyang.

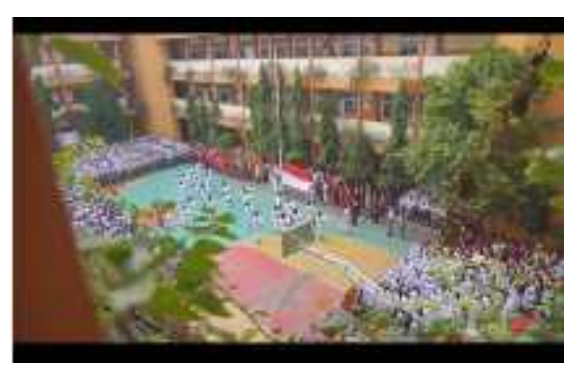

Gambar 12. Still film sekolah sedang melakukan upacara bendera 17 Agustus

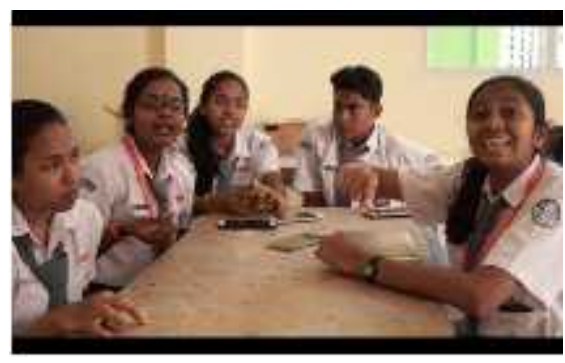

Gambar 13. Still film saat Switha memberikan pernyataannya sebagai seorang suku tamil yang berbangsa Indonesia

Pada kesempatan ini juga peristiwa saat Switha sempat beberapa kali mengucapkan kata dalam bahasa Tamil. Walaupun seperti pernyataan nenek switha di awal bahwasannya Switha berbicara Tamil secara pasif namun bukan berarti Switha tidak bisa berbahasa tamil dengan baik. Ungkapan yang dia berikan secara tidak langsung menunjukan identitas dirinya sebagai orang yang bersuku tamil.

Dalam bagian ini Setelah berbicara panjang lebar, sutradara melontarkan pertanyaan bagaimana orang yang menjadi bagian dari suku minoritas yang ada di Kota Medan, terlihat dari upaya ini penerapan cinéma vérité. Switha dan teman-temannya menjawab dengan riang bagaimana kehidupan mereka sebagai suku Tamil yang sekarang mulai di hargai secaranya nyata. Switha bercerita bagaimana dia merasa senang ketika pemerintah Kota Medan memberikan julukan Little India pada Kampung Madras tempat banyaknya orang bersuku Tamil tinggal dan memiliki usaha di daerah tersebut. Lalu dilanjutkan dengan Switha menceritakan bagaimana perasaannya menjadi seorang anak yang bersuku tamil sekaligus menjadi bangsa Indonesia.

Dari statement yang dipaparkan oleh Switha terlihat jelas bahwa pengaruh multikulturalisme dalam kehidupan sosialnya juga ikut membantu Switha 
memiliki karakter dan sifat menerima dan dapat beradaptasi dengan banyak budaya disekitarnya. Pengakuan banyak orang terhadap keberadaan mereka juga bisa menjadi pengaruh bagi kehidupan sosial mereka di kemudian hari jika tidak saling berdampingan membangun dan membantu baik mayoritas maupun minoritas.

\section{Unsur Sinematik}

Mise-en-Scene yang ada dalam film dokumenter "Niram" ini terlihat jelas dari awal pembukaan still foto keluarga Switha bahwasannya dokumenter ini memiliki hubungan dengan suku Tamil lalu ditambah shot letak geografis saat melakukan pengambilan gambar ada di Kota Medan dengan adanya gapura Little India. Kemudian dilanjutkan dengan setting halaman sekolah dimana sebagian besar dalam karya ini akan bercerita tentang interaksi sosial di lingkungan sekolah dan berpindah menuju tempat tinggal Switha sebagai subjek utama.

Film dokumenter potret Niram lebih mengutamakan mengambil gambar dengan spontan selama proses produksi berlangsung. Selain itu, interaksi antara pembuat film dengan subjek juga menjadi salah satu hal yang utama karena agar terbentuknya chemistry yang nantinya dapat mempermudah proses pengambilan gambar. Karena peristiwa pengambilan gambar sering terjadi secara mendadak, teknik handheld diterapkan hampir dari keseluruhan pengambilan gambar dalam film dokumenter Niram ini.

Lalu seluruh hasil gambar yang sudah didapatkan akan disusun menjadi satu pada tahap editing offline, online, grading, dan subtitle menggunakan software Adobe Premiere, sesuai dengan treatment dan script editing yang sudah dibuat di awal sebagai pedoman ketika memasuki pasca produksi agar dapat memudahkan proses penyuntingan. Penyusunan gambar dipilih secara seksama agar terwujudnya suatu kesatuan menjadi naratif berbentuk potret dengan penerapan cinéma vérité yang menyampaikan pesan dengan baik dalam film dokumenter potret Niram ini.

Lalu elemen suara merupakan bagian penting dalam film dokumenter potret Niram. Rode Video Mic Pro digunakan agar suara ruang dan subjek di depan kamera dapat terekam dengan baik namun beberapa kendala terjadi tetapi audio masih bisa didapatkan dan tetap dapat memberikan rangkaian informasi yang disampaikan oleh subjek walaupun tidak maksimal. Kualitas teknis suara menjadi hal penting untuk menghindari hilangnya informasi yang disampaikan oleh subjek saat pengambilan gambar berlangsung. Unsur lain yang harus diperhatikan adalah ilustrasi musik bernuansa India yang nantinya akan mendukung mood dari keseluruhan rangkaian gambar pada film dokumenter potret Niram. 


\section{KESIMPULAN}

Penggunaan genre potret dan gaya cinéma vérité dalam film dokumenter "Niram" diwujudkan dengan penerapan genre potret dan metode pemaparan cinéma vérité bagaimana perspekstif anak Suku Tamil bernama Switha dalam kehidupan multikulturalisme secara sosial bertujuan untuk memberikan informasi kepada penonton bahwasannya saling menghormati tanpa melihat perbedaan adalah hal baik dan terpuji untuk dilakukan tiap individu tanpa melihat budaya, suku, agama, ras, dan strata sosial. Proses diawali dengan riset langsung menjadi partisipan dilapangan dalam waktu yang lama dan melakukan pendekatan dengan calon subjek oleh pembuat film. Proses pendekatan yang dilakukan pembuat film dan subjek yakni Switha ikut mencari informasi dan merekam kehidupan sosial Switha di lingkungan sekolah dalam seharihari. Selain itu, proses pendekatan membangun chemistry antara pembuat film dan Switha seperti antara kakak dan adik.

Pembuat film dalam proses perwujudan karya beberapa kali menemukan kesinambungan antara kajian teori yang dijadikan acuan dengan perwujudan realitas pada film. Perwujudan film dokumenter potret ini di mana pembuat film memberikan informasi mengenai Switha diawal hingga bagaimana pendekatan yang terbangun antara pembuat film dan subjek terbangun dengan menerapkan gaya cinéma vérité untuk memiliki wewenang memprovokasi respon dan situasi subjek pada saat itu juga.

\section{DAFTAR PUSTAKA}

[1] Ayawaila, Gerzon R. 2008. Dokumenter: Dari Ide Sampai Produksi. Jakarta: FFTV-IKJ Press.

[2] Azra, Azyumardi. 2007. "Identitas dan Krisis Budaya, Membangun Multikulturalisme Indonesia." http://www.kongresbud.budpar.go.id/58\%20 ayyumardi\%20azra.htm

[3] Bernard, Curran, S. 2007. Documentary Storytelling Making Stronger and More Dramatic Non Fiction Films. London: Local Press.

[4] Fachruddin, Andi. 2012. DasarDasar Produksi Televisi. Jakarta: Kencana.

[5] Hampe, B. 1997. Making Documentary Films and Reality Videos. New York: Holt.

[6] Mahpud, Choirul. 2010. Pendidikan Multikultural cetakan ke-4. Yogyakarta: Pustaka Pelajar

[7] Nichols, Bill. 2001. Introduction to Documentary. Bloomington dan Indiana Polish: Indiana University Press.

[8] Pratista, Himawan. 2017. Memahami Film Edisi 2.Yogyakarta: Montase Press. 
Yunalistya Sakanti Putri, Agnes Widyasmoro, Lilik Kustanto

Kehidupan Multikulturalisme Switha sebagai Anak Suku Tamil di Kota Medan dalam Penyutradaraan Film

[9] Tanzil, Chandra, dkk. 2010. Pemula

Dalam Film Dokumenter: Gampang-

gampang Susah. Jakarta: In-Docs.

[10] Wibowo, Fred. 2007. Teknik

Produksi Program Televisi. Jakarta: Pinus

Book Publisher. 
Sense Vol 3 | No 1 | Mei 2020 